\title{
PRINTED MATERIALS AVAILABLE FROM THE NALLD PUBLICATIONS CENTER
}

YOU must be a NALLD member to use this service. In many cases the reprint itself is free; however, you must provide a selfaddressed, $9 \times 12$ inch manila envelope that is stamped with the proper return postage. The order form lists the weight of each item; you must total up the weight of all items ordered and compute your postage after deciding whether you want the information to be sent by First Class or Third Class mail. Requests for materials will be honored only when made on the order form and accompanied by the properly stamped self-addressed manila envelope.

At present we cannot distribute items in quantity; however, you have our permission to reproduce or copy any material received from the Publications Center provided you identify the source by the line:

Reprinted by permission of the National Association of Language Laboratory Directors

NALLD members are encouraged to offer items for possible inclusion in the Publications Center. Please address Mr. Charles P. Richardson, Director, NALLD Publications Center, Ellis Hall, Ohio University, Athens, Ohio 45701. We would especially like routine work forms which schools actually use in their operations. Naturally, you must agree that others can reproduce any material provided to our Publications Center.

Members are encouraged to offer suggestions on other categories which we should add to our list.

\begin{tabular}{|c|c|c|}
\hline $\begin{array}{l}\text { Category } \\
\text { Item }\end{array}$ & & Weight \\
\hline Number & Item Description, Title, and Contributing School & in $0 z$. \\
\hline
\end{tabular}

1.01.00 NALLD OFFICIAL BUSINESS-Reports to Members

.01 Copy of NALLD Constitution, revised in May, $1967 \quad 50$

.01B Copy of NALLD Constitution, revised in May, $1969 \quad 50$

.02 Minutes of the Second Final Organizational Meeting of NALLD $\quad .25$

.03 Memo of 2 August 1965, giving further information of NALLD and its plans 


\section{PRINTED MATERLALS AVATLABLE}

Category

Item

Number

Item Description, Title, and Contributing School

Weight in $\mathbf{~ o z}$.

.04 Minutes of NALLD Midwest Regional Meeting (Dec. 1965, Chicago, Ill.)

.05 Minutes of First Annual Business Meeting (April 1966, DAVI Convention)

.06 Minutes of Southern Regional Meeting (1966 Atlanta, Georgia)

.07 Minutes of Eastern Regional Meeting (Dec. 1966, N. Y. at MLA Convention) Also, Membership Report from Secretary-Treasurer for Dec. 1966.

.08 Minutes of Second Annual Business Meeting (April 1967, Atlantic City, N. J., at DAVI Convention)

\subsubsection{NALLD SELECTED SPEECHES AND POLICY STATEMENTS}

.01 "Should There Be a Language Laboratory Director at the Secondary Level?" Speech by Dr. J. Michael Moore, San Diego City Schools. (NALLD first business meeting, April 1966, San Diego). 2.00

.03 "Objectives, Tests and Motivation," by Carl Pond

.04 Dossier sur La Formation Professionnelle de Directeurs de Labatoire de Langues, Guy Plastre

1.03.00 NALLD NEWSLETTERS-Back Issues

.01 Volume I, Number 1 (February, 1966)

.02 Volume I, Number 2 (September, 1966)

.03 Volume I, Number 3 (February, 1967)

.04 Volume II, Number 1 (December, 1967)

.05 Volume II, Number 2 (February, 1968)

.06 Volume II, Number 3 (May, 1968)

.07 Volume III, Number 1 (October, 1968)

.08 Volume III, Number 2 (December, 1968)

.09 Volume III, Number 3 (March, 1969)

.10 Volume III, Number 4 (May, 1969)

.11 Volume IV, Number 1 (October, 1969)

2.00.00 SAMPLE COPIES OF WORKING SYSTEMS: DESCRIPTIONS INSTRUCTION MANUALS

2.01.01 Job Description: Language Laboratory Director (may we have your schools, please?) 
Printed Materials Available

Category

Item

Number

Item Description, Title, and Contributing School

Weight

in $\mathbf{~ o z}$.

2.02.00 Job Description: Chief Technician (Technical Supervisor)

.02 University of Hawaii

2.03.00 Job Description: Laboratory Secretary

(May we have your school's description, please?)

2.04.00 Job Description: Tape Processing Supervisor

(May we have your school's description, please?)

2.05.00 Job Description: (Student) Open-Hour Proctor

(May we have your school's description, please?)

2.06.00 Job Description: (Student) Recording Session Technician (May we have your description please?)

2.07.00 Job Description: (Student) Minor Repair and Maintenance Technician (May we have your description please?)

2.08.00 Job Description: (Student) Tape Library Processing

.01 University of Wisconsin-Madison (Five separate booklets covering different phases: Stamping, Duplicating, Banding and FillingIn Worksheets, Typing Final TICC Guide and Final Check)

2.09.00 Tape Locator Catalog-Sample Copy

.01 University of Wisconsin-Madison

2.10.00 Student Orientation Guide to Language Laboratories

.01 University of Wisconsin-Madison

2.11.00 Faculty Semester Information Packet

.01 University of Wisconsin-Madison $\quad 1.50$

3.00.00 SAMPLE COPIES OF BLANK FORMS USED

3.01.00 In Language Lab Office and Laboratory Administration

.01 University of Wisconsin-Madison 3.50

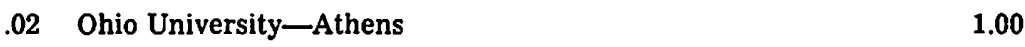

.03 Wheaton College-Norton, Massachusetts $\quad .50$

.04 State University College-New Paltz, New York 1.00

3.02.00 In the Language Laboratories

.01 University of Wisconsin-Madison $\quad 2.00$

.02 Ohio University-Athens, Ohio $\quad .75$

.03 Mount Mary College $\quad .50$ 


\section{Printed Materials Available}

Category

Item

Number

Item Description, Title, and Contributing School

Weight

in $\mathbf{~ o z}$.

3.03.00 Used by Lab Technicians for Repair, Maintenance, and Preventive Maintenance

.01 University of Wisconsin-Madison

3.04.00 Used to Process Tapes into Language Laboratory Regular Tape Library (including Recording Sessions, Duplication)

.01 University of Wisconsin-Madison

3.05.01 Dial Access Program Library Operation

.01 University of Wisconsin-Madison (preliminary forms)

4.00.00 TECHNICAL DATA PREPARED BY SCHOOLS FOR PROCURING OR PLANNING FACILITIES

.01 (Category open-contributions desired)

4.02.00 Functional and Technical Specifications for Remote Record Labs

.01 (Category open-contributions desired)

4.03.00 Functional and Technical Specifications for Dial-Access Labs

.01 Specifications for Lab Equipment California State College at Haywood

.02 "The Listening Center, The Ohio State University at Columbus, Ohio Specifications for a Remote Listening System", Director, Dr. Paul Pimsleur

4.04.00 Functional and Technical Specifications for Overhead Labs

.01 (category open-contributions desired)

4.05.00 Miscellaneous Technical Report and/or Outlines

.01 "Reasons for Using 2 Track Rather than 4 Track Tapes as Program Sources in Dial-Access Retrieval System" T. R. Goldsworthy, Univ. Wisconsin-Madison

.02 "Cost Analysis of Expanding Automatic Dial-Access Switching Systems," Workpaper T. R. Goldsworthy, Univ. of WisconsinMadison

5.00.00 PEDAGOGICAL AND OPERATIONAL ORIENTATION OF SCHOOL STAFF WHEN PLANNING FACILITIES

5.01.00 Background Information Papers for Faculty

.01 University of Wisconsin-Madison (Several papers concerning new building facilities with dial-access and remote record.) 
Printed Materials Available

Category

Item

Number

Item Description, Title, and Contributing School

Weight

in oz.

6.00.00 INFORMATION PAPERS, MEMORANDA, RESEARCH REPORTS

6.01.00 Research reports

.01 "The Electronic Classroom, the Broadcast and the Record-Play. Playback Language Laboratory: Their Contribution to Achieve. ment in Beginning Language Learning" William Flint Smith, Purdue University, Lafayette, Indiana

.02 "The Language Laboratory and the Electronic Classroom," A parison." ibid

7.00.00 LANGUAGE LAB TECHNIQUES-MATERIALS FOR COURSES AND WORKSHOPS (COURSE DESCRIPTIONS, OUTLINES, BIBLIOGRAPHIES, SAMPLE LESSONS

7.01 .00

.01 Principles and Practice of the Language Laboratory, Morehouse College

.02 "101 Terms", by permission of 3M Company. A glossary of large secondary term.

8.00.00 TAPE INDEX CORRELATION CODE (TICC) GUIDES. These guides were prepared to give close correlation between sets of tapes used at one school with their textbooks, by relating tape bands and reels with textbook pages, chapters, and grammatical topics. All these guides are predicated upon the fact that they can be subdivided. Those who would care to prepare similar guides for other textbooks are invited to do so.

8.01.00 French TICC Guides-Beginning Level

.01 Harris and Leveque, Basic Conversational French, Revised 3rcl Edition, Conversations. (Holt, 1962) Fr. 1.001.43

.02 Harris and Leveque, Basic Conversational French, Revised 3rd Edition, Grammar Units. (Holt, 1962) Fr. 1002.25

.03 Heise and Miller, A Conversational Introduction to French. (Dodd, Mead and Co., 1963) Fr: 1.003 .15

.04 Palmeri, Conversational and Cultural French. (Appleton-CenturyCrofts, 1966). Fr. 1.005.04

.05 Harris and Leveque, Basic French Reader, (New York: Holt, Rinehart and Winston, Inc.) Fr. 1.006.01 to Fr. 1.006.28, Beginning Level TICC

.06 Pond and Peyrazat, Fundamental Quick Change Audio Drills, French (Indiana Raytheon Educational Electronics, 1960) TICC No. Fr. 1009.01 to 1.009 .70 


\section{Printed Materials Available}

Category

Item

Number

Item Description, Title, and Contributing School

Weight

in oz.

8.02.00 French TICC Guides-Intermediate Level

.01 Bottke, Brief Oral French Review (Appleton, 1964) Fr. $2.001 .08 \quad .75$

.02 Harris, Intermediate Conversational French, Revised (Holt, 1966)

Fr. 2.003.

.03 Mondelli, French Conversational Review Grammar 2nd Edition (American Book Co., 1961) Fr. 2.005.10

.05 Thomas H. Brown Langue et Literature McGraw Hill, New York, N. Y. 1967 (Fr. 2.009.01 to Fr. 2.009.26)

8.03.00 French TICC Guides-Advanced Level

.01 Leon, Exercises Systmatiques de Prononciation Francaise. (Paris: Libraries Hachette et Larousse, 1964) Fr. 3.001.06

.02 Valdman, A Drillbook of French Pronunciation (Harper and Row, 1964) Fr. 3.004.20

.03 Pleasants, Pronunciation Francaise (New York, Goldsmith's Music Shop, Inc. 1956) TICC No. Fr. 3.002.01 to Fr. 3.002.06

.04 Delattre, Advanced Training in French Pronunciation TICC No.: Fra. 3.003.01 to Fr. 3.003.02

.05 EMC Corp., The Sounds of French (St. Paul, Minn., 1965), TICC No.: Fr. 3.005 .01 to Fr. 3.005.02

.06 Teamac Programmed Phonetics Elaine Burroughs Encyclopedia Britanica 1961 (Fr. 3.006.01 to Fr. 3.006.06)

8.04.00 German TICC Guides-Beginning Level

.01 Mathieu, Quick Change Audio-Drills in Fundamental German. (Regents Publishing Co., 1961) Gr. 1.001.72

.02 Scherer, Contemporary German. (McGraw-Hill, 1966) Gr. 1.002.45

.05 Wangler, Instruction in German Pronunciation (St. Paul, Minn., EMC Corp. 1966) TICC No. Gr. 1.006.01 to Gr. 1.006.05

8.05.00 German TICC Guides-Intermediate Level

.01 Mathieu, Expanded Quick-Change Audio-Drills in German (Re. gents Publishing Co., 1963) GR. 2.001.82

.02 Rehder, et al., Lesen und Denken. (Holt, 1964) Gr. 2.002.18

.03 Griesbach, Deutsche Sprachlehre fuer Auslaender. Munich: Max Hueber, 1964 Gr. 2.004.04

.04 Drath, Typisch Deutsch? (New York, Holt Rinehart, and Winstom. Inc., 1961) Fr. 2.003.01 to Gr. 2.003.17 
.05 McCluney, Jr., ed., Lesen Und Horen (New York W. W. Norton Co., Inc. 1963) TICC No. Gr. 2.007.01 to Gr. 2.007.10

.60 Beeninger and Pietschmann Ich Lausche dem Leben W. W. Norton and Company, Inc. 1963 N. Y. Gr. 2.008.01 to Gr. 2.008.03

8.06.00 German TICC Guides-Advanced Level

.01 (Not completed)

8.07.00 Italian TICC Guides-Beginning Level

.01 Hall Basic Conversational Italian, (Holt, 1963) It. 1.001.24

.02 Hall and Bartoli, Basic Conversational Italian Dialogues (N. Y.: Holt, Rinehart, and Winston, Inc. 1964) TICC No. It. 1.002.01 to It. 1.002.04

8.08.00 Italian TICC Guides-Intermediate Level

.01 (Not completed)

8.09.00 Italian TICC Guides-Advanced Level

.01 (not completed)

\subsubsection{Spanish TICC Guides-Beginning Level}

.01 MIA, Modern Spanish, 1st Edition (Harcourt, Brace, 1960) Sp 1.001 .45

.02 MIA, Modern Spanish, 1st Edition (Dialogues) (Harcourt, Brace, 1960) Sp. 1.002 .04

.03 Maestas, Teacher's Manual and Guide-Spanish Linguatapes Series M. (St.; Louis: Edu-Tek, Inc., 1962) Sp 1.003.08

.04 Rogers, Spanish for the First Year (MacMillian Co., 1964) Sp. 1.005.19

.05 Leslie, Spanish for Conversation (Ginn and Co. 1959) Sp. 1.006.23 $\quad .75$

.06 Florit, Escuche y Acierte. (McGraw-Hill 1965) Sp. 1.009.23 1.50

.07 Florit; Esche Y Acierte. (McGraw-Hill, 1956) Sp. $1.009 .06 \quad 1.00$

.08 Turk, Foundation Course in Spanish, Revised (Chicago: D. C. Heath and Co., 1965) TICC No.: Sp. 1.010.01 to Sp. 1.010.14 1.00

.09 Fernandez, Por Esas Espanas, Revised (New York: Holt, Rinehart, and Winston, 1964) TICC No.: Sp. 1.014.01 to 1.014.24 1.00

.10 Bolinger, et al, Modern Spanish, A Project of the Modern Language Association, (Harcourt, Brace, and World, Inc. 1966. N. Y.) TICC No.: 1.015 .01 to $\mathrm{Sp}$. 1.015 .70 


\section{Printed Materials Available}

Category

Item

Number

Item Description, Title, and Contributing School

Weight

in $\mathbf{~ o z}$.

.11 MIA Modern Spanish Revised-Edited for Lab Sessions (Dwight L. Bolinger et al, N. Y. Harcourt, Brace and World, Inc., 1966) TICC No. Sp. 1.024.01 to 1.024.69)

.12 C. T. Poltz Pattern Drills Electronic Teaching Laboratories Washington, D. C. Sp. 1.017 to Sp. 1.017 .50

8.11.00 Spanish TICC Guides-Intermediate Level

.01 O'Connor, et al., Oral Drill in Spanish, 2nd Edition (HoughtonMifflin Co., 1963) Sp. 2.001.22

.02 Wise, Teacher's Manual and Guide for Linguatapes Pattern Drills Series A (St. Louis, Edu-Tek, 1961) Sp. 2.002.20

.03 Ugarte, Gramatica Espanola de Repaso (Odyssey Press, 1958) Sp. 2.003 .08

.04 Yates, Imaginacion y Fantasi (Holt, 1960) Sp. 2.004 .22

.05 Giner de los Rios. Nolfi, (Anna) and Nolfe, (Luke), Tierras de Espana, New York, Holt, Rinehart, Winston, 1962) TICC No. Sp. 2.0051 to Sp. 2.005.20

.06 Mondelli and Ponterotto, A Conversational Spanish Review Gram-

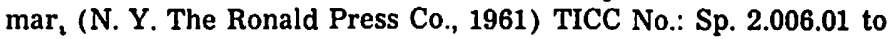
2.006.15

.07 Hesse and Orjuela, SPANISH CONVERSATIONAL REVIEW GRAMMAR (New York: American Book Company, 1964)

.08 Da Silva and Lovett, A Concept Approach to Spanish (New York, Harper and Row, 1965).

8.13.00 Portuguese TICC Guides-Beginning Level

.01 C. Leroy, Portuguese Para Principiantes, 2nd Edition (Univ. of Wisconsin Extension, Madison, Wisconsin 1964) Pg. 1.001.38

.02 C. Leroy, Portuguese Phonetics, Manuscript Edition Pg. 2.005.15

8.16.00 Russian TICC Guides-Beginning Level

.01 Galina Stilman and William E. Harkins, Introductory Russian Grammar, (Blaisdell, 1964) 1st Ed. Ru. 1.001.42

.03 V. Kamenew, CLT-Series-Pattern Drills (Washington, D. C. Electronic Teaching Laboratories, 1963)

\subsubsection{Russian TICC Guides-Intermediate Level}

.01 S. Khavronina, Russian as We Speak it, (Foreign Language Publishing House, Moscow, Russia. n.d.-probably early '60's Ru. 2.001.04 
Printed Materials Available

Category

Item

Number

Item Description, Title, and Contributing School

Weight

in oz.

8.19.00 Norweigian TICC Guides-Beginning Level

.01 Einar Haugen and Kenneth G. Chapman, Spoken Norwegian, Revised, 2nd Edition. (Holt, Rinehart and Winston, 1964) No. 1.001.26 1.25

8.22.00 English TICC Guides-Beginning Level

.01 English Language Institute, English Pronunciation, English Sentence Patterns, English Pattern Practices, 1st Edition (Univ. of Michigan Press, 1964) En. 1.001.35

8.25.00 Linguistics TICC Guides-Beginning Level

.01 The Sounds of Language (University of California, Berkeley) Li. 1.001 .10

.02 H. A. Gleason, Jr. An Introduction To Descriptive Linguistics (Holt, Rinehart, and Winston, 1965)

8.26.00 Arabic TICC Guides-Beginning Level

.01 W. Lehn and F. Abboud. Beginning Cairo Arabic. 1.00

8.28.00 Bulgarian TICC Guides-Beginning Level

.01 Carleton T. Hodge, et al., Foreign Service Institute, Bulgarian Basic Course (Washington, D. C., Department of State. 1967) 1.00

8.30.00 Swedish TICC Guides-Beginning Level

.01 Nils-Gustav Hildeman, Learn Swedish, (Almqvist and Wiksell, Stockholm 1959). 


\section{Printed Materials Available}

To obtain materials send this order form properly completed along with a $9 \times 12$ inch self-addressed manila envelope properly stamped with the correct postage to:

\section{Mr. Charles Richardson, Director \\ NALLD Publications Center \\ Ellis Hall \\ Ohio University \\ Athens, Ohio 45701}

Please send items checked below to the following address:

Name .................... Title

Address

City

State

Zip Code

Item No. Quantity

1.01 .01

.02

.03

.04

.05

.06

.07

.08

1.02 .01

.03

.04

1.03.01

.02

.03

.04

.05

.06

.07

.08

.09

.10

.11

2.02 .02

2.08.01

2.09 .01

2.10 .01

2.11 .01

3.01 .01

.02

.03

.04

3.02.01

.02

.03

3.03.01
( )

( )

( )

( )

( )

( )

( )

( )

( )

( )

( )

( )

( )

( )

( )

( )

( )

( )

( )

( )

( )

( )

( )

()

()

( )

()

()

()

()

()

( )

( )

()
Item No. Quantity

3.04.01

3.05 .01

4.03.01

.02

4.05.01

.02

5.01 .01

6.01 .01

.02

7.01 .01

.02

8.01 .01

.02

.03

.04

.05

.05

8.02 .01

.02

.03

.05

8.03.01

.02

.03

.04

.05

.06

8.04.01

.02

.05

8.05.01

.02

.03

.04

.05
( )

( )

( )

( )

( )

( )

( )

( )

( )

( )

( )

( )

( )

( )

( )

( )

( )

( )

( )

( )

( )

()

( )

( )

()

( )

()

()

()

()

()

()

()

()
Item No. Quantity

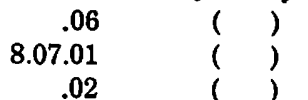

8.10 .01

8.01 .02

.03

.04

.05

.06

.07

.08

.09

.10

.11

.12

8.11.01

.02

.03

.04

.05

.06

.07

.08

8.13.01

.02

8.16 .01

.03

8.17 .01

8.19 .01

8.22 .01

8.25 .01

.02

8.26 .01

8.28 .01

8.30 .01 